\title{
Personal Business Ethics Perception: A Study of Vietnamese Adults
}

\author{
TRÀ̀N HÀ MINH QUÂN \\ University of Economics HCMC - quan.tran@isb.edu.vn
}

\begin{tabular}{|c|c|}
\hline ARTICLE INFO & ABSTRACT \\
\hline $\begin{array}{l}\text { Article history: } \\
\text { Received: } \\
\quad \text { May } 102014 \\
\text { Received in revised form } \\
\text { June } 132014 \\
\text { Accepted: } \\
\end{array}$ & $\begin{array}{l}\text { As the world of business is becoming more globalized and diverse, } \\
\text { business ethics also becomes a complicated and frequently } \\
\text { controversial topic. Organizations as well as individuals are fully } \\
\text { aware that business ethical issues can have a great influence on the } \\
\text { public attitudes toward them, and unethical behaviors and conducts } \\
\text { can destroy trust. In turn, ethical leaders and employees can }\end{array}$ \\
\hline $\begin{array}{l}\text { Keywords: } \\
\text { business ethics, codes of } \\
\text { conduct, ethical maturity, } \\
\text { moral development, } \\
\text { Vietnam. }\end{array}$ & $\begin{array}{l}\text { lead to organization's sustainability. Today's workplace has a high } \\
\text { demand for ethical behaviors of all employees. This study examines } \\
\text { the personal business ethics perceptions of } 964 \text { Vietnamese adults } \\
\text { based on age, gender, management experience, and code of conduct } \\
\text { by using Clark \& Clark's (1966) Personal Business Ethics Scores } \\
\text { (PBES) measure. The results demonstrate that there is a significant } \\
\text { difference in personal business ethics perceptions on each variable. It } \\
\text { appears that younger Vietnamese adults have higher personal } \\
\text { business ethics scores than older adults. Vietnamese females scored } \\
\text { higher than males. People with management experience have lower } \\
\text { scores while those who have not experienced codes of conduct have } \\
\text { higher scores than those who have experienced codes of conduct. In } \\
\text { this study, literature review on ethics, corruption perception index of } \\
\text { Vietnam, limitations, and implications are also provided. }\end{array}$ \\
\hline
\end{tabular}




\section{INTRODUCTION}

Decision making at all levels of work and management involves ethics. Leaders, managers, and employees are dealing with ethical issues daily. However, business ethics seem to be controversial as there is no universally-accepted approach for resolving ethical issues. An ethical social and business culture can help prevent bribery, corruption, and ethical misconduct. Ethical culture in organizations provides a platform for efficiency, productivity, and profitability (Ferrell \& Ferrell, 2013).

Since the normalization of diplomatic relations between the U.S. and Vietnam in 1995, Vietnam has developed remarkably and become a strategic partner of ASEAN and many other economies in the world. With its fast integration to the global economy, the foreign investment environment has been improved significantly. However, not many Western people know clearly the Vietnamese business culture as well as the professional ethical standards. Only a few researches have been conducted in Vietnam to examine its cultural values and background, workforce characteristics, and ethical standards. Among many approaches to understanding business ethics is to look at personal morals, characteristics, and ethical maturity (Ferrell \& Ferrell, 2006). The purpose of this study is twofold: (i) to examine if demographic variables such as age or gender make a difference in the ethical maturity of respondents in Vietnam; and (ii) to investigate if the Clark \& Clark's (1966) Personal Business Ethics Scores (PBES) measure, a tool developed in the U.S., is applicable to the Vietnamese culture. It provides an analysis of Vietnamese adults' level of ethical maturity based on age, gender, management experience, and codes of conduct. The key research question is, "Do age, gender, management experience and codes of conduct actually make a difference in the ethical maturity level of Vietnamese adults?" Understanding the ethical maturity of Vietnamese adults may provide greater insights into their ethical behavior, which can help government, communities and organizations build a strong ethical culture.

\section{BUSINESS ETHICS IN VIETNAM}

Concepts of business ethics are relatively new in Vietnam. After the Vietnam War, Vietnam rebuilt its economy with a centrally-planned economic mechanism where government had an absolute power to control all business activities, and state-owned enterprises (SOEs) were considered the only legitimate economic form (Nguyen, 2011). This system enforced compliance and obedience to orders and instructions from 
higher authorities. Thus, being ethical simply meant "doing what you are told to do." However, the economic program "Doi Moi", or renovation, which was launched in 1986, helped Vietnam open its market and integrate to the regional and international markets. People have had opportunities to expose to issues such as consumer rights and product and service quality as well as the concepts of business ethics. However, the rule of thumb in business ethics remains largely as complying with the laws and regulations.

In Vietnam, corruption and bribery are perhaps the most serious business ethics issues and challenges. The World Bank in 2007 identified the causes of corruption as "poorly designed economic policies, underdeveloped civil society, low levels of education and weak accountability of public institutions" (Segon \& Booth, 2010). Though Vietnam has attracted a great volume of foreign investment, top managers are often hesitant about their decisions to enter Vietnam when they see its Corruption Perception Index (CPI) scores ranked by Transparency International. The CPI measures the perceived levels of public sector corruption (Transparency International, 2013). As shown in Table 1, Vietnam has a CPI score of 31 and ranked 116 among 177 surveyed countries and territories. In the Asia-Pacific Region, Vietnam ranked 18 out of 29 countries. In contrast, China has a score of 40 and ranked 80 while New Zealand had the best ranking with a CPI score of 91 out of a possible 100 point-scale.

Table 1: Corruption Perception Index (2013): Asia-Pacific Region

\begin{tabular}{cccc}
\hline Country Rank & Regional Rank & Country / Territory & CPI 2013 Score \\
\hline 1 & 1 & New Zealand & 91 \\
5 & 2 & Singapore & 86 \\
9 & 3 & Australia & 81 \\
15 & 4 & Hong Kong & 75 \\
18 & 5 & Japan & 74 \\
31 & 6 & Bhutan & 63 \\
36 & 7 & Taiwan & 61 \\
48 & 8 & Brunei & 60 \\
& 9 & Korea (South) & 55
\end{tabular}




\begin{tabular}{|c|c|c|c|}
\hline 53 & 10 & Malaysia & 50 \\
\hline 80 & 11 & China & 40 \\
\hline 83 & 12 & Mongolia & 38 \\
\hline 91 & 13 & Sri Lanka & 37 \\
\hline 94 & 14 & India & 36 \\
\hline 94 & 14 & Philippines & 36 \\
\hline 102 & 16 & Thailand & 35 \\
\hline 114 & 17 & Indonesia & 32 \\
\hline 116 & 18 & Nepal & 31 \\
\hline 116 & 18 & Vietnam & 31 \\
\hline 119 & 20 & Timor-Leste & 30 \\
\hline 127 & 21 & Pakistan & 28 \\
\hline 136 & 22 & Bangladesh & 27 \\
\hline 140 & 23 & Laos & 26 \\
\hline 144 & 24 & Papua New Guinea & 25 \\
\hline 157 & 25 & Myanmar & 21 \\
\hline 160 & 26 & Cambodia & 20 \\
\hline 175 & 27 & Afghanistan & 8 \\
\hline 175 & 27 & Korea (North) & 8 \\
\hline
\end{tabular}

Source: Transparency International (2013)

According to World Economic Forum (2013), Vietnam has a Global Competitiveness Index Score of 4.18 out of a possible 7-point scale and ranked 70 out of 144 countries. Figure 1 shows that corruption is among the most problematic factors for doing business in Vietnam. This suggests that Vietnam is experiencing significant corruption issues and that it will negatively impact the country's economic advantages and growth opportunity. 


\section{Figure 1: The Most Problematic Factors for Doing Business in Vietnam}

The most problematic factors for doing business

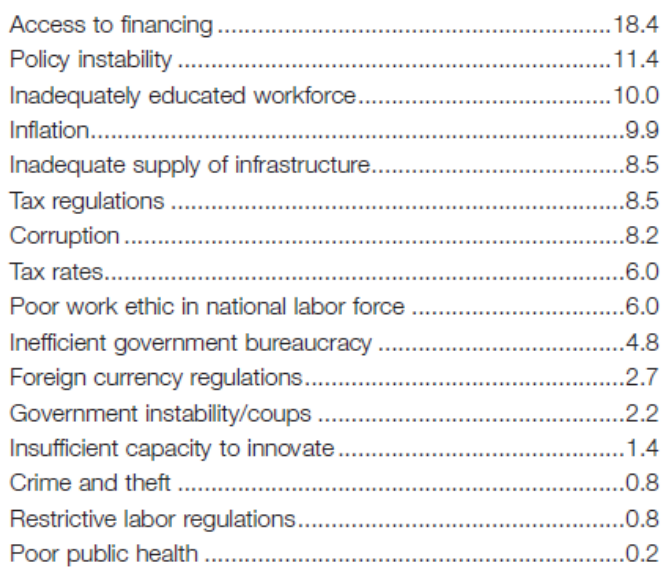

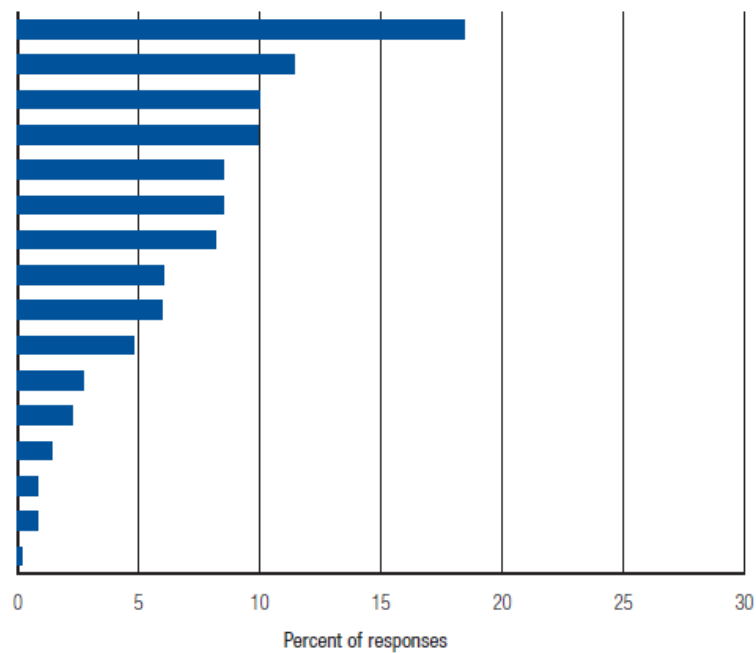

Note: From the list of factors above, respondents were asked to select the five most problematic for doing business in their country and to rank them between 1 (most problematic) and 5. The bars in the figure show the responses weighted according to their rankings.

Source: World Economic Forum (2013, p.388)

\section{a. Age and Ethics:}

Research in ethical maturity has found mixed results regarding the relationship between age and ethical and moral development. While some researches, e.g. Cannon (2001), Hyppolite (2003), Chavez (2003), Ariail (2005), and Huang (2006), found that age can be a factor to one's moral cognizance or ethical development, others found no relationship between age and moral development (Poorsoltan et al., 1991; Evans, 2004; Galla, 2006; Heron, 2006; and Freeman, 2007). In his empirical study, Cannon (2001) found evidence to support the notion that age is a predictor of moral development. In his 2003 research, Hyppolite found that there was a significant difference in the average $\mathrm{P}$-score for moral development between older and younger respondents. More particularly, older participants scored higher than younger participants did. Hyppolite concluded that an individual's level of ethical development is likely to increase as he/she is aging (Hyppolite, 2003, p. 139). In a study on banking employees, Chavez (2003) found supports for the notion "older is wiser" since he found that banking employees who are 30 years of age and older have higher moral development than banking employees who are less than 30 years of age (pp. 58-59). 
On the other hand, two studies by Galla (2006) and Heron (2006) found no significant effect of age on the moral development scores of participants. Freeman conducted a study among "knowledge management" and "non-knowledge management" firms in 2007 and found that age had no significant relationship with moral development in either type of firms (Freeman, 2007, p. 92). As Kohlberg's Cognitive Moral Development theory suggests that the level of moral reasoning of an individual should increase as he/she is aging, this study hypothesized that:

Hypothesis 1: There is a statistically significant difference in PBES among age groups of Vietnamese respondents.

\section{b. Gender and Ethics:}

Similar to the research results of age and ethical maturity, research on gender difference in ethics maturity could not find strong supports on either direction. On the support side, Beltramini et al. (1984) conducted a study on college students and found that female students were more concerned with business ethics issues than their male counterparts. Another study on college students conducted by Onyebuchi (2011) found similar results. Onyebuchi (2011) concluded that female students were more ethical than their male counterparts. In a study on marketing professionals, Akaah (1989) found that females showed a higher level of judgments on ethics than their male counterparts. In a study on senior and managerial auditors, Shaub (1994) found a significant difference in the moral development scores between males and females in the same positions. In particular, female auditors scored higher than their male counterparts. A similar result was found in a study on large public accounting firms conducted by Bernardi \& Arnold (1997). They found that female managers scored higher on moral development than male managers.

On the contrary, many studies found no strong evidence to support the differences in ethics maturity between male and females. In a study of 530 largest accountancy programs in North America, Schmidt \& Madison (1998) found that there was no significant difference between male and female chairs in the perceived importance of ethics for either the accounting or business curricula. Nguyen, Lee \& Mujtaba (2013) found that there was no significant difference in the personal business ethics scores between male and female college students. Nguyen et al. (2014) found no significant difference in the personal business ethics scores between male and female Thai working adults. With that in mind, this study hypothesized that: 
Hypothesis 2: Vietnamese female respondents will have PBES that are equivalent to or greater than Vietnamese male respondents.

\section{c. Management Experience and Ethics:}

Management experience seems to have impacts on the ethical maturity level. However, academic studies have indicated that the management experiences were not always related positively to the manager's moral judgment level (Kennedy, 2003, p. 75). Hyppolite's study (2003) found that the rank and position of respondents were not positively related to their moral development. In a cross-cultural study between U.S. and Japanese expatriate managers in Taiwan, Huang (2006) found that the ethical reasoning abilities of the managers were not related to their level of management education. Nguyen et al. (2014) found no significant difference in the personal business ethics scores between Thai working adults who had management experience and those who did not. On the contrary, Mujtaba (1997) claimed that there was a significant difference in the personal business ethics scores between respondents who had five or more years of management experience and those who had less than five years of management experience. Nguyen et al. (2013) claimed that business students with management experience had a higher level of ethical maturity than those without management experience. With that in mind, this study hypothesized that:

Hypothesis 3: Vietnamese respondents who do not have management experience will have PBES that are equivalent to or greater than those who have management experience.

\section{d. Code of Conduct and Ethics:}

Code of conduct is one of several approaches including government regulation and corporate models of ethical behaviors that organizations use to attain high ethical standards (Berkman, 1977; Boling, 1978; Kramer, 1977; and Allen, 1977). It is one of the most prevalent approaches used by businesses as a tool to improve ethical conducts (Tsalikis \& Fritzsche, 1989). In a survey of major corporation CEOs, White and Montgomery (1980) found that about three quarters of the medium-sized firms, and about half of the smaller companies have codes of conduct. According to Purcell (1977) and Weber (1981), corporations should institutionalize ethics at the top management because "good ethics is good business in the long run," and code of conduct is one of the three principal methods of ethics institutionalization. Boling (1978) argues that the code of ethics is necessary to serve as the "leading edge of law." 
Fritzsche \& Becker (1982) argue that codes of conduct should be used as a guide when managers faced ethical problems. In general, researches tend to support the notion that codes of conduct can make a difference in individual's level of ethical maturity. With that in mind, the author proposed the following hypothesis:

Hypothesis 4: Vietnamese respondents who have not experienced codes of conduct will have PBES that are equivalent to or greater than those who have experienced codes of conduct.

\section{RESEARCH MODEL, METHODOLOGY AND ANALYSIS}

\section{a. Model and Methodology:}

This study used PBES introduced by Clark \& Clark (1966) to examine the impact of age, gender, management experience, and code of conduct on moral maturity. The research question is whether these factors make a difference in the ethical maturity of Vietnamese individuals. According to Figure 2, the independent variables affecting one's moral maturity are age, gender, management experience, and code of conduct, while the dependent variable is moral maturity, which is represented by the PBES scores.

Figure 2: Research Model and Variables

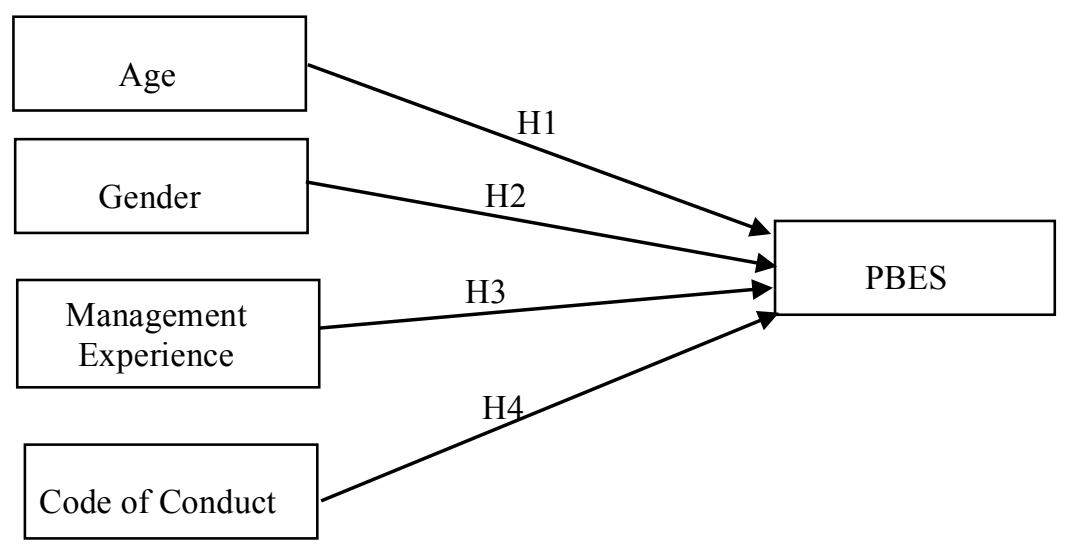

Clark \& Clark's (1966) PBES measure was translated into Vietnamese and followed a strict back-translation process to ensure the equivalence of the measures in both the Vietnamese and English languages. It was confirmed that the meaning of backtranslated version and the original version did not vary much and there was no need to make any change to the back-translated version. 
This study targeted Vietnamese adults who are seventeen years of age and above. Questionnaires were sent to Vietnamese people in Hà Nội and HCMC, which are the two largest cities of the country. Using convenience sampling method, the author obtained respondents through universities and business organizations in both public and private sectors. Participants were informed of the purpose of this research and were guaranteed total confidentiality and anonymity. This study used both hard copy and online weblink to collect the data.

Clark \& Clark's PBES measure consists of eleven questions which represent the Personal Business Ethics Scores (PBES). The PBES, which measures a person's level of commitment to personal integrity in business decisions, represent a total score between 11, indicating low personal business ethics for the eleven scenarios, to 55, indicating very high personal business ethics for these dilemmas. Researchers can compare the total added scores for the eleven dilemmas (that can range from 11 to 55) or use the average mean which can range from 1 to 5 based on the Likert scale. Table 2 shows the PBES scores and descriptions.

Table 2: PBES Scores and Descriptions

\begin{tabular}{cc}
\hline SCORES & DESCRIPTIONS \\
\hline $50-55$ & Very high range \\
$44-49$ & High range \\
$38-43$ & Moderately high range \\
$32-37$ & Moderately low range \\
$26-31$ & Low range \\
$11-25$ & Very low range \\
\hline
\end{tabular}

SPSS software was used for data analysis and hypothesis testing. This study used One-way ANOVA and t-test at 0.05 level of significance to compare differences of the means of independent samples.

As seen in Table 3, there were 401 male respondents (41.6\%) and 563 female ones (58.4\%). Of these respondents, 470 were in the $17-25$ age bracket (48.8\%); 279 in the 26-35 bracket (28.9\%); 175 in 36-45 bracket (18.2\%); 34 in 46-55 bracket (3.5\%); and only 6 were 56 and above $(0.6 \%)$. There were 353 respondents who had management 
experience (36.6\%) and 526 respondents had experienced the codes of conduct $(54.6 \%)$.

Table 3: Demographic Variables $(\mathrm{N}=964)$

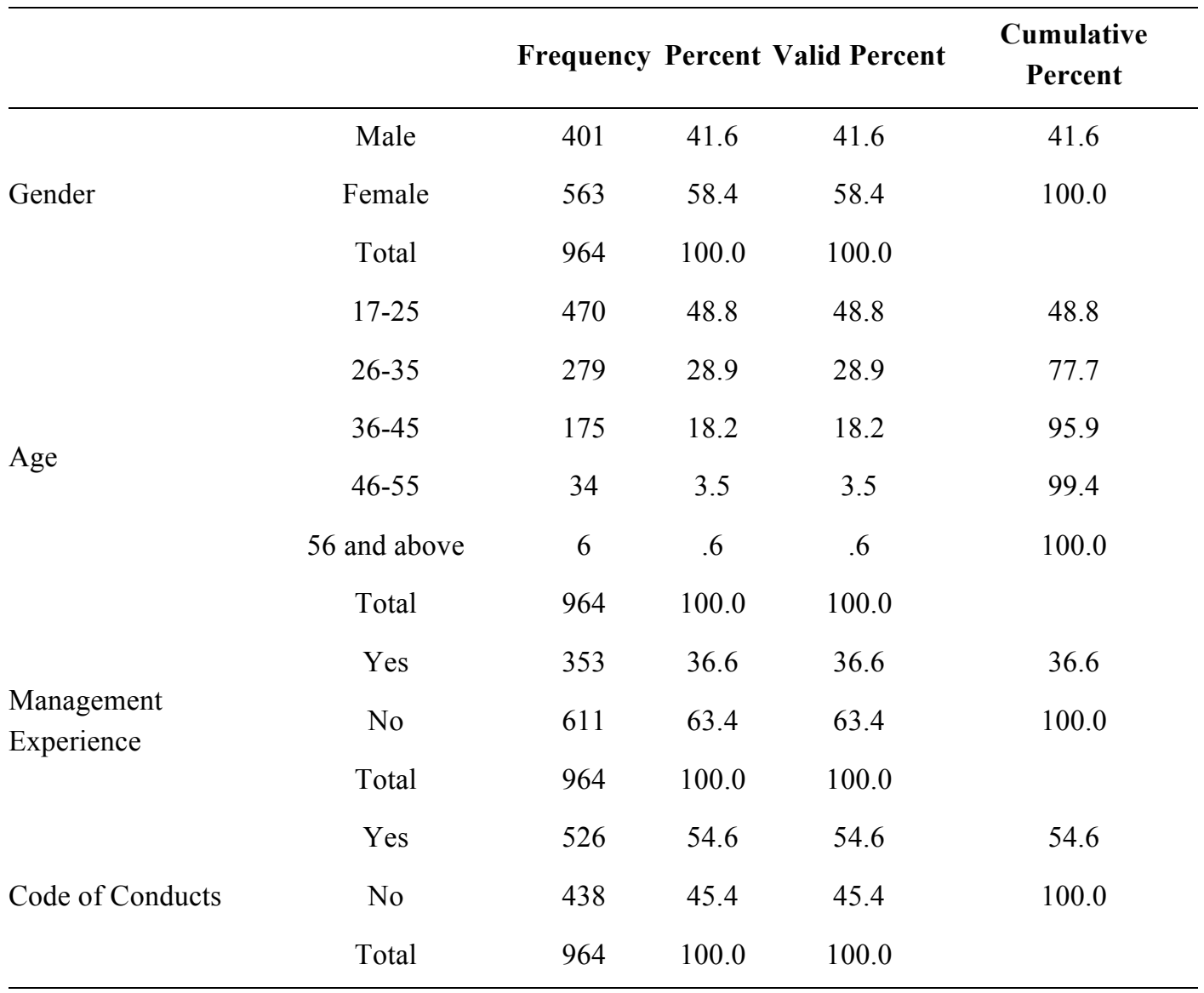

\section{b. Analysis and Results:}

As presented in Table 4.1, the average PBES score of Vietnamese adults in various age groups falls between "moderately low range" and "moderately high range" with respondents who are 56 and above getting the highest $(\mathrm{M}=39.17)$ and respondents who are in the 36-45 age bracket scoring the lowest $(M=33.67)$. One-way ANOVA test results, as seen in Table 4.2, show a statistically significant difference between these age groups $(\mathrm{F}=32.481 ; \mathrm{p}=0.000)$. Thus, hypothesis one is supported. In particular, as shown in Table 4.3, significant difference is seen between respondents from 17-25 age 
groups and respondents from 26-35 age groups, 36-45 age groups, and 46-55 age groups.

Table 4.1: Descriptives of PBES of Vietnamese adults in different age groups

\begin{tabular}{|c|c|c|c|c|c|c|}
\hline & \multirow{2}{*}{$\mathbf{N}$} & \multirow{2}{*}{ Mean } & \multirow{2}{*}{ Std. Deviation } & \multirow{2}{*}{ Std. Error } & \multicolumn{2}{|c|}{ 95\% Confidence Interval for Mean } \\
\hline & & & & & Lower Bound & Upper Bound \\
\hline $17-25$ & 470 & 37.8511 & 5.92591 & .27334 & 37.3139 & 38.3882 \\
\hline $26-35$ & 279 & 33.9749 & 5.03757 & .30159 & 33.3812 & 34.5686 \\
\hline $36-45$ & 175 & 33.6686 & 4.67002 & .35302 & 32.9718 & 34.3653 \\
\hline $46-55$ & 34 & 34.5882 & 4.67824 & .80231 & 32.9559 & 36.2205 \\
\hline 56 and above & 6 & 39.1667 & 4.95648 & 2.02347 & 33.9652 & 44.3682 \\
\hline Total & 964 & 35.8631 & 5.76269 & .18560 & 35.4988 & 36.2273 \\
\hline
\end{tabular}

Table 4.2: ANOVA Test

\section{Sum_PBES}

\begin{tabular}{lccccc}
\hline & Sum of Squares & df & Mean Square & F & Sig. \\
\hline Between groups & 3815.681 & 4 & 953.920 & 32.481 & .000 \\
Within groups & 28164.245 & 959 & 29.368 & & \\
Total & 31979.925 & 963 & & & \\
\hline
\end{tabular}

Table 4.3: Post Hoc Tests-Multiple Comparisons

\section{Sum_PBES}

Tukey HSD

$\begin{array}{llll}\text { (I) Age } & \text { (J) Age } \quad \text { Mean Difference (I-J) } \begin{array}{c}\text { Std. } \\ \text { Error }\end{array}\end{array}$ Sig. $\frac{95 \% \text { Confidence Interval }}{\text { Lower Bound Upper Bound }}$

\begin{tabular}{rrrrrrr}
\hline $17-25$ & $26-35$ & $3.87615^{*}$ & .40957 & .000 & 2.7568 & 4.9955 \\
& $36-45$ & $4.18249^{*}$ & .47990 & .000 & 2.8709 & 5.4940 \\
& $46-55$ & $3.26283^{*}$ & .96242 & .007 & .6325 & 5.8931 \\
& 56 and above & -1.31560 & 2.22648 & .976 & -7.4005 & 4.7693 \\
\hline $26-35$ & $17-25$ & $-3.87615^{*}$ & .40957 & .000 & -4.9955 & -2.7568
\end{tabular}




\begin{tabular}{ccccccc} 
& $36-45$ & .30634 & .52257 & .977 & -1.1218 & 1.7345 \\
& $46-55$ & -.61332 & .98440 & .971 & -3.3037 & 2.0770 \\
& 56 and above & -5.19176 & 2.23607 & .139 & -11.3029 & .9194 \\
\hline $36-45$ & $17-25$ & $-4.18249^{*}$ & .47990 & .000 & -5.4940 & -2.8709 \\
& $26-35$ & -.30634 & .52257 & .977 & -1.7345 & 1.1218 \\
& $46-55$ & -.91966 & 1.01567 & .895 & -3.6955 & 1.8561 \\
& 56 and above & -5.49810 & 2.25001 & .105 & -11.6473 & .6511 \\
\hline $46-55$ & $17-25$ & $-3.26283^{*}$ & .96242 & .007 & -5.8931 & -.6325 \\
& $26-35$ & .61332 & .98440 & .971 & -2.0770 & 3.3037 \\
& $36-45$ & .91966 & 1.01567 & .895 & -1.8561 & 3.6955 \\
& 56 and above & -4.57843 & 2.39969 & .314 & -11.1367 & 1.9799 \\
\hline 56 and & $17-25$ & 1.31560 & 2.22648 & .976 & -4.7693 & 7.4005 \\
above & $26-35$ & 5.19176 & 2.23607 & .139 & -.9194 & 11.3029 \\
& $36-45$ & 5.49810 & 2.25001 & .105 & -.6511 & 11.6473 \\
\hline & $46-55$ & 4.57843 & 2.39969 & .314 & -1.9799 & 11.1367 \\
\hline
\end{tabular}

*: The mean difference is significant at the 0.05 level.

Table 5 showed the t-test results of the last three hypotheses. Hypothesis 2 is supported $(\mathrm{t}=-6.654 ; \mathrm{p}=0.000)$ as these female adults have a higher level of ethical maturity scores $(M=36.88)$ than their male counterparts $(M=34.43)$ even though both PBES scores fell in the moderately low range according to Table 2. Hypothesis 3 is supported $(\mathrm{t}=-2.778 ; \mathrm{p}=0.006)$ as Vietnamese respondents who do not have management experience have a higher level of ethical maturity scores $(M=36.25)$ than those who have management experience $(M=35.19)$ even though both PBES scores fell in the moderately low range according to Table 2. Finally, hypothesis 4 is supported $(\mathrm{t}=-5.550 ; \mathrm{p}=0.000)$ as Vietnamese respondents who have not experienced the codes of conduct have a higher level of ethical maturity scores $(M=36.97)$ than those who have experienced the codes of conduct $(M=34.94)$ even though both PBES scores fell in the moderately low range according to Table 2. 
Table 5: PBES Based on Gender

\begin{tabular}{|c|c|c|c|c|c|c|c|c|c|c|}
\hline \multirow[t]{2}{*}{$\begin{array}{c}\text { Hypotheses } \\
\text { (PBES) }\end{array}$} & \multicolumn{2}{|c|}{$\begin{array}{l}\text { Group } \\
\text { Size }\end{array}$} & \multicolumn{2}{|c|}{ Group Mean } & \multicolumn{2}{|c|}{$\begin{array}{l}\text { Levene's Test } \\
\text { for Equality of } \\
\text { Variances }\end{array}$} & \multicolumn{4}{|c|}{ t-test for Equality of Means } \\
\hline & 1 & 2 & 1 & 2 & $\mathbf{F}$ & Sig & $\mathbf{t}$ & df & $\begin{array}{l}\text { Sig. (2 } \\
\text { tailed) }\end{array}$ & $\begin{array}{c}\text { Mean } \\
\text { Difference }\end{array}$ \\
\hline H2: Gender & 401 & 563 & 34.43 & 36.88 & .403 & .526 & -6.654 & 962 & .000 & -2.45135 \\
\hline $\begin{array}{l}\mathrm{H} 3: \\
\text { Management } \\
\text { experience }\end{array}$ & 353 & 611 & 35.19 & 36.25 & .785 & .376 & -2.778 & 962 & .006 & -1.06671 \\
\hline $\begin{array}{l}\text { H4: Code of } \\
\text { Conduct }\end{array}$ & 526 & 438 & 34.94 & 36.97 & .285 & .594 & -5.550 & 962 & .000 & -2.03762 \\
\hline $\mathrm{p}<.05$ & & & & & & & & & & \\
\hline
\end{tabular}

\section{DISCUSSION AND IMPLICATIONS}

It was hypothesized that age, gender, management experience, and code of conducts made a difference in the Personal Business Ethics Scores of Vietnamese adults in this sample, and this study found supports for all of the hypotheses. First of all, there is a difference between various age groups, and it appeared that the youngest age group (17-25) has higher personal business ethics scores than all other groups except for the 56-and-above age group. This means that younger Vietnamese adults are less tolerant of unethical behaviors in business than older adults. This could be because they have not experienced real-world business as much as the older adults have.

Second, there is a difference in the personal business ethics scores between male and female adults. Female adults have higher scores than their male counterparts. This finding supports the assumption that females are more ethical than males. There is a gender difference in ethics perceptions. Perhaps this is because females are more likely to be "considerate" as to how their decisions will impact people and society. They may be less tolerant of unethical practices.

Third, there is a difference between the personal business ethics scores of Vietnamese respondents who have management experience and those who do not have management experience. The finding is somehow surprising that respondents with no management experience scored higher than those who have management experience. 
This could be because managers often deal with ethical dilemmas more than employees so they may be more tolerant of unethical practices than the employees.

Finally, this study detects a difference in personal business ethics scores between respondents who have experienced the codes of conduct and those who have not experienced the codes of conduct. The finding is also surprising when those who have not experienced the codes of conduct have a higher level of ethical maturity scores than those who have experienced the codes of conduct.

\section{LIMITATIONS}

There are several limitations in this study. First of all, this study used a convenience sampling group. Future studies can examine more specific groups such as people with similar working backgrounds who come from other provinces besides Hà Nội and HCMC. Second, the sample size, although relatively decent, was still small. Thus, the results of this study cannot be generalized to a larger group of the population. In addition, this study only examined the difference in personal business ethics scores of Vietnamese adults based on several demographic variables. Future research can investigate into other non-demographic factors. Vietnam is a developing economy that has a long history of having public sector as a major economic force. Hence, future studies can investigate the personal business ethics scores of those who have government work experience and those who work in private sector to see if government work experience makes a difference in the level of ethical maturity of the employees. Also future studies should examine the personal business ethics scores of other Asian people, such as adults in China, Thailand, Singapore, Malaysia, and Philippines. Finally, longitudinal studies are recommended to examine how changes in demographic variables and other economic factors can affect the personal business ethics perception.

\section{CONCLUSION}

Vietnam has become a strategic partner in the global business community and played an important role not only in Southeast Asia but also in the world market. Together with global integration come the corruption and ethical challenges. These challenges, if not dealt with properly and immediately, can negatively impact the public trust and foreign investors' confidence in Vietnam.

A strong ethical culture, which can help organizations, communities and countries achieve sustainable growth, starts at the top. Country, community, and organization 
leaders should build such an ethical culture by understanding the individual business ethics perception of their subordinates, committing to higher ethical standards, providing rigorous ethics training programs, and enforcing and controlling their ethics programs.

This study empirically examined the difference in personal business ethics perceptions of Vietnamese adults based on age, gender, management experience, and code of conduct. The findings have shed light on the difference in the level of ethical maturity of Vietnamese adults. By using a commonly-used instrument developed in a Western culture, the PBES measure, on a Vietnamese sample, this study further satisfies the need for cross-cultural examination, which is of utmost importance since Vietnam is a relatively new research site. Academic researchers, government leaders, business practitioners, and the like, can benefit from the results of this study. The researcher emphasized the importance of a strong ethical social and business culture that can help Vietnam as well as communities and organizations prevent bribery and corruption and thus achieve the sustainable growth and prosperity

\section{References}

Akaah, I.P. (1989), "Differences in Research Ethics Judgments between Male and Female Marketing Professionals", Journal of Business Ethics, 8(5): 375-381.

Allen, F. T. (1977), “Should Corporate Ethics Be Regulated?” Management Review, 66: 16-17.

Ariail, D. L. (2005), "Personal Values, Moral Development, and Their Relationship: A Study of Certified Public Accountants", Doctoral Dissertation, Nova Southeastern University.

Beltramini, R.F., R.A. Peterson \& G. Kozmetsky (1984), “Concerns of College Students Regarding Business Ethics”, Journal of Business Ethics, 3: 195-200.

Berkman, H. W. (1977), “Corporate Ethics: Who Cares?” Journal of the Academy of Marketing Science, 5: 154-167.

Bernardi, R.A. \& D.F. Arnold (1997), “An Examination of Moral Development within Public Accounting by Gender, Staff Level, and Firm", Contemporary Accounting Research, Winter, 653-658.

Boling, T. E. (1978), “The Management Ethics Crisis: An Organizational Perspective.” Academy of Management Review, 3: 360-365.

Cannon, C. (2001), "Does Education Increase Moral Development? A Re-Examination of the Moral Reasoning Abilities of Working Adult Learners", Doctoral Dissertation, Nova Southeastern University. 
Chavez, J. (2003), "Morality and Moral Reasoning in the Banking Industry: An Ethical and Cognitive Moral Development Examination", Doctoral Dissertation, Nova Southeastern University.

Clark, J. W. \& S. J. Clark (1966), Religion and Moral Standards of American Businessmen, Cincinnati: Southwestern Publishing Co.

Evans, S. P. K. (2004), “A Study of Cognitive Moral Development Theory and Moral Maturity of African-American Business Professionals", Doctoral Dissertation, Nova Southeastern University.

Ferrell, O.C. \& L. Ferrell (2006), Managing the Risks of Business Ethics and Compliance, adapted from "Understanding How to Teach Business Ethics by Understanding Business Ethics" in Sheb L. True, O.C. Ferrell \& L. Ferrell (2005), Fulfilling Our Obligations: Perspectives on Teaching Business Ethics, Kennesaw State University Press.

Ferrell, F. \& O. Ferrell, (2013), Business Ethics: Ethical Decision Making and Cases, $9^{\text {th }}$ ed, Mason, Ohio: South-Western Cengage Learning.

Freeman, W. J. (2007), "Moral Maturity and the Knowledge Management Firm", Doctoral Dissertation, Nova Southeastern University.

Fritzsche, D.J. \& H. Becker (1982), "Business Ethics of Future Marketing Managers", Journal of Marketing Education, 2-7.

Galla, D. (2006), "Moral Reasoning of Finance and Accounting Professionals: An Ethical and Cognitive Moral Development Examination”, Doctoral Dissertation, Nova Southeastern University.

Heron, W. T. (2006), “An Examination of the Moral Development and Ethical Decision-Making of Information Technology Professionals”, Doctoral Dissertation, Nova Southeastern University.

Huang, C. (2006), "Cross-Cultural Ethics: A Study of Cognitive Moral Development and Moral Maturity of U.S. and Japanese Expatriate Managers in Taiwan and Taiwanese Managers", Doctoral Dissertation, Nova Southeastern University.

Hyppolite, A. (2003), “The Influence of Organizational Culture, Ethical Views and Practices in Local Government: A Cognitive Moral Development Study", Doctoral Dissertation, Nova Southeastern University.

Kennedy, W. J. (2003), “A Study of the Moral Reasoning Skills of Proactive and Reactive Organizational Management”, Doctoral Dissertation, Nova Southeastern University.

Kramer, O.P. (1977), "Ethics Programs Can Help Companies Set Standards of Content", Administrative Management, 38: 46-49.

Mujtaba, B. G. (1997), Business Ethics Survey of Supermarket Managers and Employees, UMI Dissertation Service, Bell and Howell. 
Nguyen, L.D. (2011), "Organizational Characteristics and Employee Overall Satisfaction: A Comparison of State-Owned and Non-State-Owned Enterprises in Vietnam", South East Asian Journal of Management, 5(2): 135-158.

Nguyen, L.D., K-H. Lee \& B. G. Mujtaba (2013), "Business Ethics Perceptions of Future Business Managers: An Examination of Business Students at a State College in Florida”, presented at the 2013 International Business Conference of the Society for Advancement of Management (SAM), March 21-24, 2013, Arlington, Virginia.

Nguyen, L.D., K-H. Lee, B. G. Mujtaba \& S. Silanont (2014), "Business Ethics Perceptions of Working Adults: A Study Based on Gender, Age, Management Experience, and Ethics Training in Thailand", International Journal of Asian Business and Information Management, 5(2).

Onyebuchi, V. N. (2011), "Perceptions of Male and Female Accounting Majors and NonAccounting Majors on Ethics in Accounting”, International Journal of Business \& Social Science, 2(17): 74-78.

Poorsoltan, K., S. Amin \& A. Tootoonchi (1991), "Business Ethics: Views of Future Leaders", SAM Advanced Management Journal, 56(1): 4-9.

Purcell, T.V. (1977), "Institutionalizing Ethics into Top Management Decisions", Public Relations Quarterly, 22, 15-20.

Schmidt, J. J., \& R.L. Madison (1998), "Do Male and Female Accountancy Chairs Perceive Ethics and Communication the Same?" Management Accounting Quarterly, 9(3): 29-33.

Segon, M. \& C. Booth (2010), "Managerial Perspectives of Bribery and Corruption in Vietnam", International Review of Business Research Papers, 6(1), 574-589.

Shaub, M.K. (1994), "An Analysis of the Association of Traditional Demographic Variables with Moral Reasoning of Auditing Students and Auditors", Journal of Accounting Education, Winter, 1-26.

Transparency International (2013), “Corruption Perception Index Data for 2013”, retrieved from $<\mathrm{http}$ ://transparency.org $>$.

Tsalikis, J. \& D. Fritzsche (1989), "Business Ethics: A Literature Review with a Focus on Marketing Ethics", Journal of Business Ethics, 8: 695-743.

Weber, J. (1981), "Institutionalizing Ethics into the Corporation”, MSU Business Topics, 29: 47-52.

White, B.J. \& B. R. Montgomery (1980), "Corporate Codes of Conduct", California Management Review, 23(2): 80-87.

World Economic Forum (2013), “The Global Competitiveness Report 2013-2014”, retrieved from $<$ http://www3.weforum.org/docs/WEF_GlobalCompetitivenessReport_2013-14.pdf $>$. 